\title{
Management of the health workforce in facing COVID-19: disinformation and absences in Brazil's Public Policies
}

\author{
Gestão da força de trabalho em saúde e COVID-19: desinformação \\ e ausência de Políticas Públicas no Brasil
}

\begin{abstract}
Silvana Nair Leite (https://orcid.org/0000-0002-5258-9684) ${ }^{1}$
Mirelle Finkler (https://orcid.org/0000-0001-5764-9183) ${ }^{2}$

Jussara Gue Martini (https://orcid.org/0000-0003-2629-293X) ${ }^{3}$

Ivonete Heidemann (https://orcid.org/0000-0001-6216-1633) ${ }^{3}$

Marta Verdi (https://orcid.org/0000-0001-7090-9541) ${ }^{2}$

Fernando Hellmann (https://orcid.org/0000-0002-4692-0545) ${ }^{2}$

Maria Fernanda Vásquez (https://orcid.org/0000-0001-5165-5646) ${ }^{2}$
\end{abstract}

${ }^{1}$ Programa de Pós-

Graduação em Farmácia,

Departamento de Ciências

Farmacêuticas, Universidade

Federal de Santa Catarina.

Campus Universitário Darcy

Ribeiro, Trindade. 88000-

000 Florianópolis SC Brasil.

silvana.nair.leite@ufsc.br

${ }^{2}$ Programa de Pós-

Graduação em Saúde

Coletiva, Universidade

Federal de Santa Catarina.

Florianópolis SC Brasil.

${ }^{3}$ Programa de Pós-

Graduação em Enfermagem,

Departamento de

Enfermagem, Universidade

Federal de Santa Catarina.

Florianópolis SC Brasil.

\begin{abstract}
The objective of this research was to analyse federal government interventions in crisis management and the consequences for health professionals. This is a documentary-type qualitative research. Brazilian Federal regulations referring to work and health education produced during the pandemic emergency of COVID-19, published from January 28 to June 2, 2020, were identified. Of the total of 845 documents, 62 were selected in accordance with the inclusion criteria and were then submitted to Thematic Content Analysis. The results and discussions were grouped into four categories: workforce management, workforce protection, workforce training and academic-workforce relationship. Absence of a federal coordinating actions and policies for desinformation were identified. This lacking mechanisms for coordination contributed decisively to the tragic epidemiological situation still underway, especially in terms of the exposure of health workers to the risk of contamination, revealed in the extremely high rates of professionals infected or killed by COVID-19 in Brazil and the failure to control the pandemic in the population. Keywords Workforce, Health personnel, COVID-19, Pandemics, Public policy
\end{abstract}

Resumo Objetivou-se evidenciar as estratégias implementadas no Brasil quanto à força de trabalho em saúde no contexto da pandemia da COVID-19 e analisar as intervenções do Governo Federal na gestão da crise e suas consequências aos profissionais de saúde. Trata-se de pesquisa de abordagem qualitativa do tipo documental. Foram identificadas normativas federais brasileiras alusivas ao trabalho e educação na saúde produzida durante a emergência pandêmica da COVID-19, publicadas no período de 28 de janeiro a 2 de junho de 2020. Do total de 845 documentos encontrados, 62 foram selecionados segundo os critérios de inclusão, os quais foram submetidos à Análise de Conteúdo Temática. Os resultados e discussões foram agrupados em quatro categorias: gestão da força de trabalho, proteção da força de trabalho, capacitação da força de trabalho e relação academia-força de trabalho. Observou-se a ausência de uma politica federal coordenadora de ações orientadas à governança da força de trabalho em saúde para o enfrentamento da pandemia no Brasil. Esta lacuna colaborou decisivamente para a trágica situação epidemiológica ainda em curso, sobretudo em termos da exposição de trabalhadores de saúde ao risco de contaminação, revelada nos altíssimos indices de profissionais infectados ou mortos por COVID-19 no Brasil.

Palavras-chave Força de trabalho, Profissionais da saúde, COVID-19, Pandemias, Políticas públicas 


\section{Introduction}

Since the World Health Organization (WHO) characterized the spread of Sars-CoV-2 as a pandemic on March 11, 2020, healthcare systems across high, lower and middle-income countries have been put under tremendous pressure to control the spread of the novel coronavirus'. The pandemic, together with a fragile and questionable economic model, has worsened global disparities by weakening the already precarious essential services (health and education) of the poorest countries, such as those in Latin Amer$\mathrm{ica}^{2}$. Issues related to lack of infrastructure, resources and the capacity to acquire equipment have been of crucial importance. The major responsibility of health systems is to maintain and support frontline health care workers, who are putting their lives on the line $\mathrm{e}^{1,3}$.

Government leaders and regulators need to help expand capacity and ensure the full use of the workforce under safe conditions throughout the pandemic ${ }^{3,4}$. In this sense, it is not only imperative to treat infected people and prevent new cases, but it is also of great importance to ensure that there are sufficient healthcare professionals (HCP) and a safe working environment ${ }^{1,4,5}$.

Around the world, risks and harm to healthcare professionals have been reported. In the United States, a total of 9,282 health care professionals were confirmed with COVID-19 and reported to the CDC in April. This is likely an underestimate because HCP status was available for only $16 \%$ of reported cases nationwide ${ }^{4}$. In Wuhan, a total of $3.5 \%$ patients that presented with severe disease or death were health care workers ${ }^{6}$. In April 2020, Brazil already presented more than $50 \%$ of the deaths of nursing professionals from all over the planet $^{7}$. In July 2020, the number of confirmed cases in HCP was 173,000 (about 10\% of total cases). The nursing workforce was the most affected professional category with more than 46,626 professionals in the field infected by COVID-19, 519 of whom had died by Jan $13^{\text {th }} 2021^{8}$.

The risk to healthcare workers is one of the greatest vulnerabilities of healthcare systems worldwide. To protect HCP is one of the major challenges and should be the crucial mission for health systems and institutions. The media and scientific publications have denounced the shortages in personal protective equipment for frontline health care workers. All the scientific recommendations agree that testing frontline health care staff is a priority ${ }^{1,9}$, together with ensuring conditions for self-isolation, social isolation and quarantine and utilization of training, knowledge and protocols ${ }^{1,10}$ as well as developing an evidence-based menu of interventions from which careful selection may occur, and which are tailored to various workplace settings ${ }^{11}$. Effective strategies towards improving mental health should also be provided to the frontline professionals ${ }^{12}$, because of high rates of reported symptoms of depression, anxiety, insomnia and distress ${ }^{13,14}$.

Since late May 2020, three months after the first reported case of coronavirus in Brazil, an average of more than 1000 daily deaths has been recorded. Currently, Brazil has one of the fastest growing coronavirus epidemics in the world ${ }^{15}$, with more than 8,195,637 confirmed cases - the second largest number in the world - and more than 204,690 deaths, according to official data ${ }^{16}$. Brazil has become one of the epicentres of the COVID-19 pandemic and is experiencing "a public health disaster"17. The vacuum of actions by the federal government to command the fight against the pandemic only aggravates the difficulty faced in the country, due to conditions in such an unequal society with a huge population of people in situations of extreme vulnerability ${ }^{18}$.

The focus of this research was the policies implemented by the Brazilian government, specifically with regard to the health workforce tackling the COVID-19 pandemic. The health workforce concept adopted is the contingent of people engaged in actions whose primary intent is to enhance health, who are at many different stages of their working lives, work in many different organisations and under changing conditions and pressures $^{19}$. The objective of the study was to highlight the strategies implemented in the management of the health workforce in Brazil and to analyse the way the federal government has dealt with the pandemic in terms of its consequences for health professionals.

\section{Methodology}

This research employed a predominantly qualitative approach, of the documentary type. Documentary research uses diverse sources such as statistical tables, newspapers, magazines, reports and official documents. It is a type of research that uses primary sources, that is, data and information that have not yet been treated scientifically or analytically ${ }^{37}$.

A survey of all federal regulations and legislation produced during the pandemic emergency of COVID-19 in Brazil was carried out. The 
search included documents published between $28 / 01 / 2020$ and $02 / 06 / 2020$, on the two official websites that compile them: The National Council of Health Secretaries (CONASS) ${ }^{20}$ and the Presidency of the Republic/ General Secretariat ${ }^{21}$. Both constantly update the publications and offer a direct link to their content, which is published in the Official Federal Gazette. The selection had as inclusion criteria: regulations and laws related to the pandemic and to Education and/or Health; and that were federal in scope.

Seven hundred seventy-one documents related to COVID-19 were found and organized in an Excel ${ }^{\circledR}$ spreadsheet to assist in the data collection stage. Of these, 706 were removed due to duplication or because they did not meet the inclusion criteria, resulting in a total of 65 documents. After a critical and thorough reading, it was possible to develop an overview of the published federal acts, according to a list of predetermined categories, namely: Workforce Management; Workforce Protection; Teleworking; Workforce-Academia Relationship; and Workforce Training.

From this first analysis, we sought to identify the need to complement the investigation with documents that addressed the national combat of the pandemic within the scope of actions in Education and Health. Thus, a second stage of collecting directives was carried out, including technical notes, dispatches, technical reports and protocols published on the websites of the federal councils of Pharmacy (CFF), Medicine (CFM), Nursing (COFEN), Dentistry (CFO) as well as the Special Secretariat for Indigenous Health (SESAI), the Ministry of Education, the Brazilian Company and Hospital Services (EBSERH) and the Coordination for the Improvement of Higher Education Personnel (CAPES). In this second stage, 74 documents that met the study inclusion criteria were considered. The total number of documents was 139 .

After reading and critically evaluating each of the documents, 77 were excluded because they did not meet the inclusion criteria, resulting in 62 documents that were actually analysed. These were synthesized and allocated to one or more of the previously defined categories. For the selection of documents, the recommendations of the Preferred Reporting Items for Systematic Reviews and Meta-Analyzes (PRISMA) were used, represented in Figure 1.

Using the tableu public application, details of the characteristics of the included documents were obtained, such as temporal distribution, typology, grouping by categories and authoring in- stitutions. For the evaluation of the documents, the steps of Thematic Content Analysis were followed, which provided methodological organization and rigor to the study. In this process, it was noticed that the six previously defined categories formed four different thematic categories: workforce management, workforce protection, workforce training and academia-workforce relationship.

\section{Results and discussion}

The arrival and spread of the coronavirus in Brazil required new regulations and laws in order to minimize the impact of COVID-19 on the lives and work of people, in particular HCP, who are on the front line of resulting emergency public health measures. The two-stage review of various sites offered a total of 845 records. Of the total of official documents published in this period, the central theme of this study, federal governance of the health workforce, was present in a small portion (62 documents out of a total of 845), categorized into four different categories (Chart 1).

How well a country manages the COVID-19 crisis depends largely on how effectively the health workforce is used. Much can be done to ensure that the workforce is prepared to deal with the pandemic. According to Fraher et al. ${ }^{13}$, "government leaders and regulators will need to help expand capacity and ensure the full use of the workforce throughout the pandemic". The analysis of the standards and documents reported here identified how the Brazilian federal government has conducted the management of the health labour force in this period.

From a bibliometric point of view, analysis of the temporal distribution of the documents showed greater publication in March 2020, when the first death from COVID-19 was registered in the country (12/03). Despite the exponential worsening of the pandemic in the following months, the number of published documents decreased sharply, instead of the expected and necessary expansion (Figure 2). Such data must be analysed in the political context of the country, in which the Minister of Health in office at the beginning of the pandemic, doctor Luis Henrique Mandetta, was replaced on April 17 by Nelson Teich, a doctor from the private sector, who remained in post for just a month. Since then, the health ministry has been replacing career civil servants with military personnel, including the current interim minister. This seems to be con- 


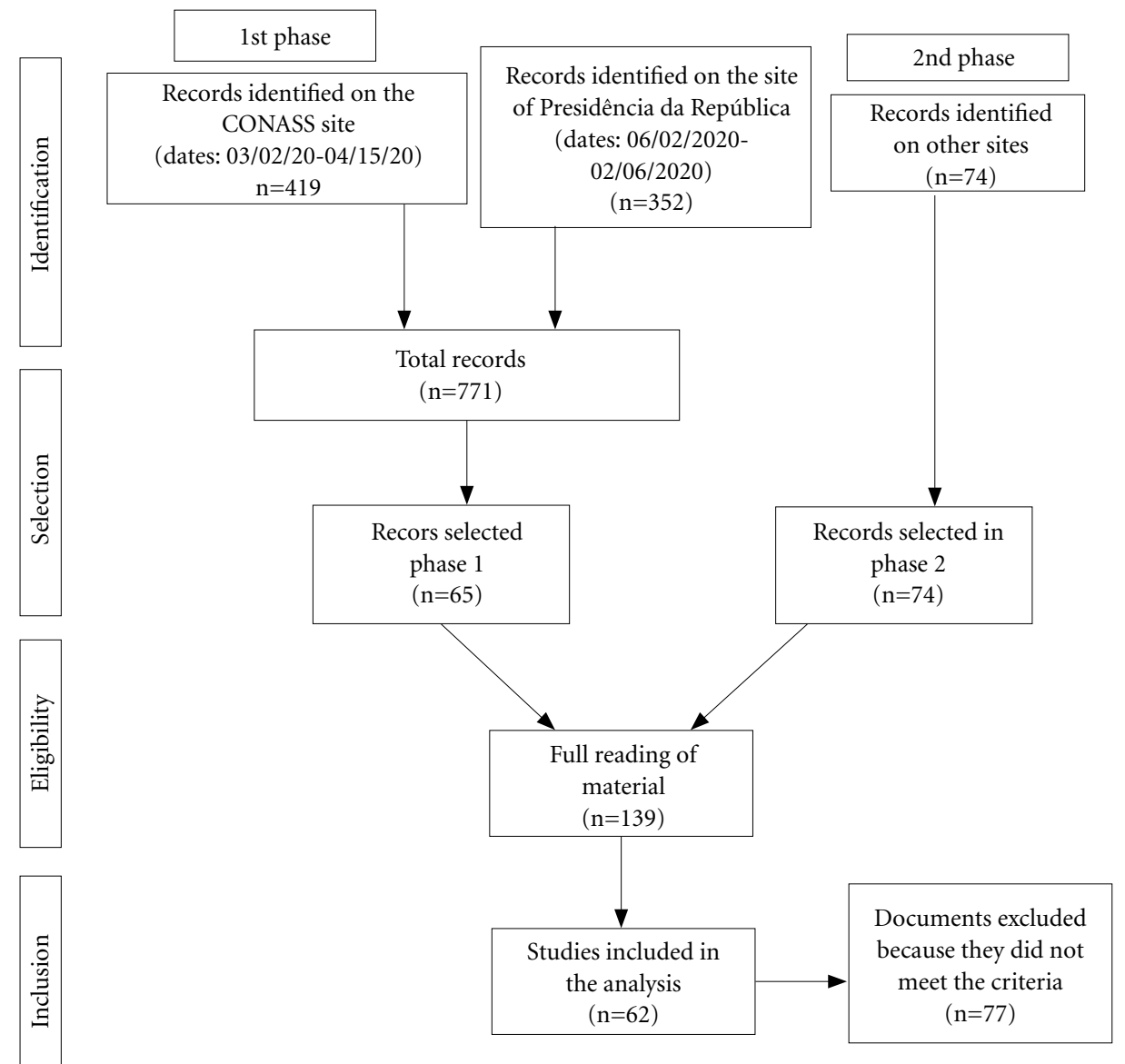

Figure 1. Flowchart of the document selection process.

Source: The authors.

tributing to the near absence, in June, of regulations regarding the orientation of the workforce in combating COVID-19.

With respect to the type of records analysed, of the 62 documents included, 22 are decrees, being the most common legislative type for administration, regulation and application of laws and regulations, as well as general provisions, reporting on the acts carried out by public bodies. This trend is related to the type of institution that published such acts, mostly the Ministry of Health. From the analysed records, publications by the Special Secretariat for Indigenous Health (SESAI) predominate, it being responsible for $22.59 \%$ of the documents, followed by the reg- ulations issued by the cabinet of the Minister of the Ministry of Health and the Secretariat of Primary Health Care (SAPS), with 19.35\% and $11.29 \%$, respectively.

Despite the profusion of regulations in the area of indigenous health, systematizing regulations, guidelines and recommendations for management and specific care to be implemented in Special Indigenous Health Districts across the country, the level of contamination among more than 155 indigenous peoples reveals the social vulnerability to which they are subjected and the failure of the federal government to protect these native peoples. The underreporting of cases and deaths from COVID-19 in the indigenous con- 
Chart 1. Analysed documents.

\begin{tabular}{|c|c|c|c|}
\hline Categories & Subcategories & \multicolumn{2}{|c|}{ Analysed Documents } \\
\hline \multirow{5}{*}{$\begin{array}{l}\text { Workforce } \\
\text { Management }\end{array}$} & Primary Care & \multicolumn{2}{|l|}{ Portaria $n^{\circ} 430^{1}$} \\
\hline & Hospitals & Lei n. $13.995^{2}$ & $\begin{array}{l}\text { Parecer normativo COFEN } \\
\text { n. } 2^{3}\end{array}$ \\
\hline & Material resources & Portarias $245^{4}, 488^{5}$ & Nota Técnica n.4 SESAI ${ }^{59}$ \\
\hline & Professional resources & $\begin{array}{l}\text { Portarias } 55^{9}, 151^{58}, 188^{6}, \\
356^{16}, 639^{7} \\
\text { Resolução RDC } 356^{8}\end{array}$ & $\begin{array}{l}\text { Edital EBSERH } 1^{10}, 2^{11} \\
\text { Editais } 5^{12}, 8^{13}, 9^{14}, 10^{15}\end{array}$ \\
\hline & Protective measures & Portaria $356^{17}, 428^{18}$ & $\begin{array}{l}\text { Lei } 13.979^{19} \\
\text { Resolução } 682^{20}\end{array}$ \\
\hline \multirow{9}{*}{$\begin{array}{l}\text { Workforce } \\
\text { Protection }\end{array}$} & $\begin{array}{l}\text { Organisation and dissemination } \\
\text { of preventative and control } \\
\text { measures }\end{array}$ & $\begin{array}{l}\text { MS/SESAI Notas } \\
\text { Informativas } 2^{21}, 6^{22} \\
\text { MS Protocolo de Manejo } \\
\text { Clínico } 3 \mathrm{~A}^{23}\end{array}$ & $\begin{array}{l}\text { MS Procedimento } \\
\text { Operacional 3B }{ }^{24} \\
\text { MS Fluxograma 3C }{ }^{25} \\
\text { MS/SAPS Protocolo } \\
\text { Específico }^{26}\end{array}$ \\
\hline & $\begin{array}{l}\text { PPE:standardisation for } \\
\text { commercialisation and use }\end{array}$ & $\begin{array}{l}\text { Resolução RDC356 } \\
\text { MS/ANVISA Nota Técnica } \\
4^{37} \\
\text { Portarias } 337^{36}, 9471^{38} \\
\text { MS Protocolo Manejo Clínico } \\
3 \mathrm{~A}^{23} \\
\text { MS Procedimento } \\
\text { Operacional 3B }{ }^{24} \\
\text { MS Fluxograma 3C }{ }^{25} \\
\end{array}$ & $\begin{array}{l}\text { MS/SAPS Protocolo } \\
\text { Específico }^{26} \\
\text { CFM despacho } 193^{27} \\
\text { MS/SAPS/CGSB Notas } \\
\text { Técnicas } 9^{28}, 16^{29} \\
\text { MS/SESAI Plano de } \\
\text { Contingência }^{35}\end{array}$ \\
\hline & $\begin{array}{l}\text { Leave of absence for groups at } \\
\text { risk }\end{array}$ & $\begin{array}{l}\text { MS/SESAI Informes Técnicos } \\
1^{30}, 2^{31}, 3^{32} 4^{33}, 5^{34}\end{array}$ & CFM despacho $193^{27}$ \\
\hline & Teleworking & $\begin{array}{l}\text { Portaria } 397^{39}, 467^{40} \\
\text { Despacho CFM } 204^{41}\end{array}$ & $\begin{array}{l}\text { Resoluções CFO } 226^{42} \mathrm{e} \\
\text { COFEN } 634^{43} \\
\text { Recomendação CREMEPE } 1^{44}\end{array}$ \\
\hline & Alteration of working processes & $\begin{array}{l}\text { MS Protocolo Manejo Clínico } \\
3 A^{23} \\
\text { MS Fluxograma } 3 C^{25} \\
\text { CFM despacho } 193^{27}\end{array}$ & $\begin{array}{l}\text { MS/SAPS/CGSB Notas } \\
\text { Técnicas } 9^{28} \text { e } 16^{29} \\
\text { MS/SESAI Informes } 1^{30}, 2^{31} \\
3^{32} 4^{33} 5^{34} \\
\text { Portaria } 337^{36}\end{array}$ \\
\hline & Provision of tests & MS/SESAI Nota Técnica $21^{45}$ & CFM despacho $193^{27}$ \\
\hline & $\begin{array}{l}\text { Priority vaccination for } \\
\text { influenza }\end{array}$ & \multicolumn{2}{|l|}{ CFM despacho $193^{27}$} \\
\hline & $\begin{array}{l}\text { Telephone service to inform } \\
\text { professionals }\end{array}$ & $\begin{array}{l}\text { MS/SESAI Notas } \\
\text { Informativas } 2^{21} \text { e } 6^{22} \\
\text { MS Protocolo Manejo } \\
\text { Clínico3A }\end{array}$ & $\begin{array}{l}\text { MS Procedimento } \\
\text { Operacional } 3 \mathrm{~B}^{24} \\
\text { MS Fluxograma } 3 \mathrm{C}^{25}\end{array}$ \\
\hline & Guaranteed working conditions & \multicolumn{2}{|l|}{ Portaria $151^{46}$} \\
\hline \multirow{2}{*}{$\begin{array}{l}\text { Workforce } \\
\text { Training }\end{array}$} & $\begin{array}{l}\text { Directions for training of } \\
\text { healthcare professionals }\end{array}$ & $\begin{array}{l}\text { MS/ANVISA Nota Técnica } \\
4^{37} \\
\text { MS/SESAI Informes Técnicos } \\
2^{31} 3^{32} 4^{33}, 5^{34}\end{array}$ & $\begin{array}{l}\text { Portarias } 492^{47}, 639^{7} \\
\text { Nota técnica } 22 \text { SESAI }^{60}\end{array}$ \\
\hline & $\begin{array}{l}\text { Offer of lifelong learning } \\
\text { courses by SUS educational } \\
\text { institutions }\end{array}$ & $\begin{array}{l}\text { OMS/OPAS } \\
\text { escolavirtual.gov.br } \\
\text { nasus.gov.br } \\
\text { uvasus.ufrn.br }\end{array}$ & $\begin{array}{l}\text { campusvirtual.fiocruz.br } \\
\text { universus.saude.gov.br } \\
\text { fiocruzbrasilia.fiocruz.br }\end{array}$ \\
\hline \multirow{3}{*}{$\begin{array}{l}\text { Academia- } \\
\text { Workforce } \\
\text { Relationship }\end{array}$} & Flexibility of classes & \multicolumn{2}{|l|}{ Portarias $343^{48}, 376^{49}, 473^{50}, 544^{51}$} \\
\hline & Inclusion of students & $\begin{array}{l}\text { Portarias } 356^{16}, 374^{62}, 492^{47} \text {, } \\
580^{52}\end{array}$ & $\begin{array}{l}\text { Resoluções COFEN } 637^{53}, \\
636^{61}\end{array}$ \\
\hline & Education and research & Editais CAPES $9^{54}, 11^{55}, 12^{56}$ & Edital CNPq $7^{57}$ \\
\hline
\end{tabular}

${ }^{\star}$ See additional material for references.

Source: The authors. 


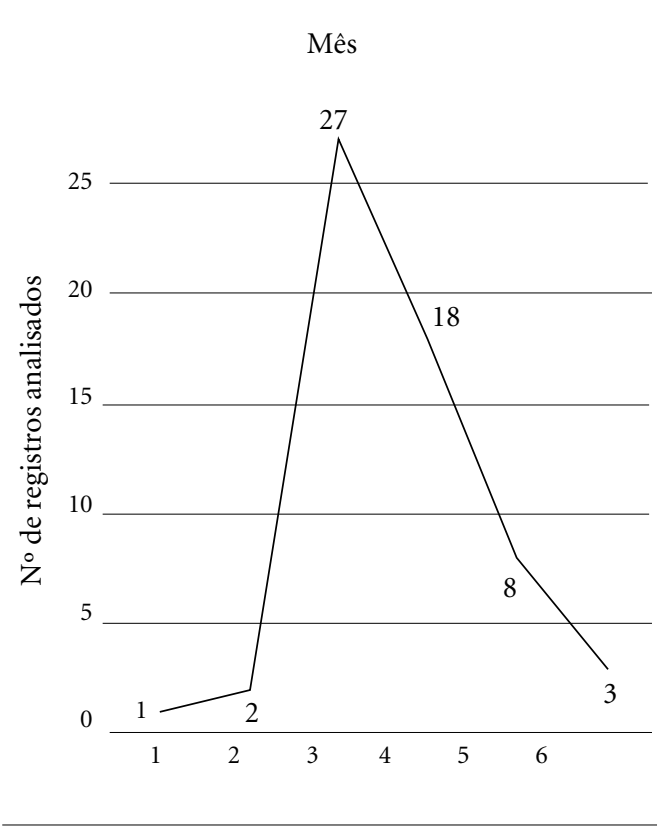

Figure 2. Records analysed by month.

text is evident, forcing indigenous leaders, with support from social organisations, to develop a registration system parallel to that of the government. While the Ministry of Health counts 39,400 indigenous people infected and 523 deaths, the parallel survey has registered more than 45,000 infections and 920 deaths ${ }^{22,23}$.

With regard to the other categories analysed, it is observed that more than half of the documents addressed some measure related to the Workforce Protection (64.29\%). Themes related to the categories of Workforce Management and Academia-Workforce Relationship were less present (in 14.29\%). The category of Workforce Training was the least identified among the documents analysed (7.14\%). Analysis of the content of the documents revealed other important issues that are discussed below in relation to each one of the four thematic categories.

\section{Workforce management}

For the management and increase in the number of professionals in services to combat the pandemic, few regulations have been published. Only a few specific notices were issued, relating to hiring of additional professionals in university hospitals, which constitute a small portion of health services. The shortage of doctors in the public health system, especially in remote and poorer regions, is a longstanding problem. Globally, investment in the health workforce is lower than is often assumed, reducing the sustainability of the workforce and health systems ${ }^{24}$. In order to solve the persistent lack of doctors in poor areas of the country, in 2013, the Brazilian government launched the More Doctors Program (PMM). As a strategy to provide professionals, the PMM had more than 16,000 vacancies, mostly filled by foreigners, reaching 12,000 Cuban physicians hired through international cooperation between Brazil and Cuba, brokered by PAHO. Despite positive evaluations by the PMM, in November 2018, this cooperation was interrupted by the Cuban government after aggressive demonstrations by President-elect Bolsonaro disqualifying the training and performance of Cuban doctors ${ }^{25}$. In the urgency of the pandemic, state governments pushed for the reintroduction of these doctors, and some were contracted again. The Doctors Council did not agree. COFEN, on the other hand, authorized the professional registration of university leavers who had already completed the course, but were awaiting graduation, in an effort to expedite entry into the work front, of nurses who had already completed the degree program. The fragility of workforce planning and actions for its resilience and sustainability that has been observed in Brazil resulted in the disastrous situation of facing a pandemic without having solved the basic demands for medical assistance that already existed.

\section{Workforce protection}

To protect health workers different specific actions were identified. The most frequently encountered were the withdrawal of workers of the groups at greatest risk for COVID-19 (people aged 60 or over, people with comorbidities or pregnant women), the use of personal protective equipment (PPE), the possibility of teleworking, and the dissemination of infection prevention and pandemic control measures. There were also recommendations for changes in work processes, especially those that generate aerosols or increase the risk for vulnerable populations, such as dental care and health worker visits to indigenous territories.

Among the measures to prevent infection and control the pandemic, we highlight the control of the care environment and the movement of users between services by disinfecting surfaces and 
instruments, hand hygiene, respiratory etiquette, use of masks by patients, ventilation of the environments, use of barriers for interpersonal spacing, rotation in the work shifts to reduce the occupation of spaces, adequate management of waste and displaying information posters in health services. The PPE were addressed in the documents from two perspectives: the specification of characteristics for their commercialization and the establishment of usage protocols. Although such recommendations have been included in several documents, guidelines for the adequate provision of PPE by the management of the services were rare, which suggests that the protection measures were envisaged more in the sense of maintaining the assistance services and controlling the pandemic itself rather than in the effective protection of workers' health and life.

Regarding the workforce and working conditions of HCP, it is identified that they live with potential sources of exposure to the virus and spread of the disease, stress and risk factors. In order to ensure working conditions that provide a reduction in virus transmission, it is essential to establish clear and robust strategies to face the pandemic ${ }^{26}$. However, the results of the present study indicate erratic and fragmented recommendations in different sectors of the Ministry of Health and other institutions. This understanding is supported by the lack of emphasis on important preventative, diagnostic and follow-up measures directed at HCP on a priority basis, and the transparent monitoring of infected workers and deaths. Added to this is the near absence of measures related to mental health and labor rights.

A report by Filho et al. ${ }^{26}$ indicates that there has been little debate about the working conditions of professionals involved in the care of people with COVID-19 in Brazil. There is a predominance of protocols and recommendations for basic individual measures, but these are insufficient to control the spread of the virus. There are reports of professionals and unions denouncing precarious working conditions, inadequate hygiene, strenuous hours, lack of training and insufficient PPE. A lack of protection for health workers was also found in an online survey of 1,456 public HCP in Brazil ${ }^{17}$. The study concluded that professionals are in a situation of extreme vulnerability, both due to the scarcity of PPE and the lack of information and government support. More than half of the interviewees affirm that they do not feel that the government supports them, this figure being higher when they evaluate the federal government $(67 \%)$ than in relation to states governments $(51 \%)$.

These conditions have also been reported in other, especially low and middle-income, countries. This highlights the difficulty for health services in addressing the growing demands of COVID-19, and the need to reflect on the consequences of the pandemic. Since workers are overloaded, there are few resources to maintain the workforce and an inability to protect the well-being of HCP (Griffin 2020) ${ }^{27}$. Amnesty International ${ }^{28}$ reports that despite the fundamental role of health and essential services workers during the pandemic, they have faced enormous challenges in doing their jobs and governments worldwide have not adequately protected them. On the contrary, many have been exposed, silenced and attacked: at least 3,000 health workers are known to have died after contracting COVID-19 in 79 countries around the world until June 2020; many others have worked in unsafe environments and unfair conditions; they have faced reprisals from the authorities and their employers for raising safety concerns, including arrests and dismissals; and in some cases have been subject to violence and stigma from members of the public.

In Brazil, it is impossible to know the total number of HCP who are falling ill and dying from COVID-19, because there is no transparency in the publication of these data. Epidemiological bulletins released by the federal government show much lower numbers of infected workers than those recorded by professional organizations, such as COFEN, which implemented a digital Observation Platform for daily monitoring of contamination or death cases among nursing professionals. However, the Ministry of Health should "collect and publish data by occupation, including categories of health and other essential workers who have been infected by COVID-19, and how many have died as a result, in order to ensure effective protection in the future, as recommended by Amnesty International. This data should be classified on the basis of prohibited grounds of discrimination, including but not limited to gender, race and workplace ${ }^{28}$.

Teleworking or remote work was a proposed method for coping with the pandemic. It may be considered as another form of accessing health care while taking care to protect HCP by ensuring social distancing, as well as protecting users of the health system. Although legislation related to teleworking predates the COVID-19 pandemic, specific rules for the current moment were issued by the Ministry of Health and the professional 
councils of the categories directly involved with patient care, such as Nursing, Pharmacy, Medicine and Dentistry. The Ministry of Health also issued regulations regarding telemedicine, instituting, on an exceptional basis, remote interaction. Telemedicine actions cover pre-clinical care, assistance support, consultation, monitoring and diagnosis, prescription of medicines through information and communication technology.

\section{Workforce training}

Published documents related to the management of the pandemic in Brazil provide, in general, guidelines for the organization of some services (such as in Primary Health Care, in the dispensing of medicines, in hospital and dental services) and protocols that can be understood as guidelines for the work of work teams, managers and health professionals. However, only a few documents guide or require the training of the workforce in the form of specific training for professionals. The chronic under-investment in HCP education and training in some countries and the mismatch between education strategies in relation to health systems and population needs are resulting in continuous shortages and low resilience of the workforce ${ }^{24}$.

Only a technical note from the National Health Surveillance Agency (ANVISA) instructs that all health professionals must be trained in the correct use of PPE, and that health services must ensure that all professionals are trained and make the appropriate PPE use. Among the specific areas or programs of the Ministry of Health, only the Special Secretariat for Indigenous Health (SESAI) advises, in its technical notes, that health professionals attend training courses on the topic offered by public institutions. It also names the courses that should be completed by all professionals. Strengthening capacity of the national health workforce in emergency and disaster risk management for greater resilience and healthcare response capacity is a general recommendation of the WHO, predating the current pandemic. The WHO has recommended that health systems develop and draw upon the capacities of the national health workforce in risk assessments, prevention, preparedness, response and recovery. This should encompass the provision of resources, training and equipment for the health workforce, who should be included in policy and implementation of operations for emergencies at local, national and international levels. Brazil has never experienced systematic preparation of its workforce for large-scale emergency situations. However, SUS (Unified Health System) has great experience and investment in "continuing education", such as the Open University of SUS (UNASUS), a network of public higher education institutions, which provides large-scale courses in e-learning and blended methods ${ }^{29}$.

The incongruity of guidelines for professional practices in facing the pandemic is a fact to be highlighted. The official federal government discourse, since the beginning of the pandemic, has been ambiguous, tending to deny scientific evidence. An emblematic example is the use of the drug hydroxychloroquine in the treatment (in early or advanced stages of the disease): even after the publication of studies that do not supply evidence of its efficacy in the management of the disease, the federal government continues (until September 2020) to encourage its prescription and use. Since June 2020, the Ministry of Health has maintained a protocol of clinical practice to encourage the prescription of this drug. Recurring official speeches also guide practices that are not scientifically based, such as denying the need for social distancing and biased use of epidemiological data. In this context, there is a lack of formal training for professionals in the management of the pandemic, plus the disinformation created by the federal government itself.

Noteworthy is the total absence of regulations, technical notes or guidelines from Department of Labour Management and Health Education of the Ministry of Health (MS), which is the secretariat designed to coordinate professional education actions for SUS. No document from the Ministry of Health explicitly addresses the need for training/ qualification of SUS workers as a whole. Furthermore, its website does not highlight initiatives to offer online courses by institutions that are maintained with resources from the Ministry itself (such as those of UNA-SUS). Several institutions and projects financed by MS have taken the initiative to create and offer a large number of places on online courses about Covid-19. However, there is no coordinated action for this offer and no general guidance for the entire SUS workforce, or for specific professional categories. This perhaps explains why only $14.2 \%$ of health professionals interviewed in an online survey ${ }^{17}$ feel prepared to deal with COVID-19. The majority (64.97\%) reported that they are not adequately prepared. Only $21.91 \%$, most of whom are doctors, report having received training. 


\section{Academia-workforce relationship}

With regard to work relations within the academic sphere, one of the most influential actions was the suspension of face-to-face classes throughout the educational system. Ministry of Education issued directives that replace face-toface classes with classes in digital media, at different levels of education, including technical, professional education. Initially this applied for 30 days, then another 30 and, finally, until Dec $31^{\text {th }} 2020$.

In response to the need to increase the number of health professionals to serve to the growing number of infected and/ or hospitalized people, the Ministry of Health launched the public call

- "Brazil Counts On Me" (Brasil Conta Comigo) - in which those in the final year of courses in Medicine, Nursing, Physiotherapy and Pharmacy are encouraged to join the front line services in coping with the pandemic. The practice of students must be preceded by a short preparatory course online via UNA-SUS. The public call fails to require the signature of an engagement agreement contract between the intern, health service, and educational institution. There is no assessment of the compatibility between the activities performed in the internship and those established in the syllabus of the undergraduate course. The public call only establishes that managers of the health units receiving students are responsible for nominating health professionals to supervise the interns. The interns have no health insurance of employment security. There is no detailed description of the activities in which they may or may not be involved.

Such measures provoked reactions on the part of the main professional bodies, such as CFM, COFEN and Brazilian Nursing Association (ABEn), who pointed out the need for caution in relation to the risks arising from these students carrying out professional service during the pandemic. ABEn and COFEN expressed their opposition to the "Brazil Counts On Me" Program, considering the demand on and overload of health service professionals as an aspect that would make the supervision of students unfeasible. Also because the shortage of Personal Protective Equipment (PPE) would put the students' health at risk ${ }^{30}$. COFEN argued that its opposition took into account that Nursing accounts for more than $60 \%$ of human resources in health and that this category is experiencing physical and mental exhaustion due to the immense de- mand generated by the pandemic. It is considered, therefore, inappropriate to expect nursing professionals to supervise trainees ${ }^{31,32}$.

On the other hand, many discussions developed in the wider society point out that the pandemic could be considered a great opportunity for the development of competences by students, improving knowledge and skills essential to the fulfilment of what is specified in the National Curriculum Guidelines for undergraduate courses in the health field. However, they emphasize that it is necessary to provide for the safety of service users, professionals and students, as well as to guarantee the quality of health care for the population $^{32}$. The positions of ABEn and COFEN are similar to the decisions of the American Association of Medical Schools, which discouraged student participation in tackling the pandemic ${ }^{32}$.

At the international level, reactions to the early entry of students in the health field into the job market has also provoked discussions ${ }^{33}$. Some countries prohibit healthcare students from having any interaction with COVID-19 patients, while others recruit students from the final years of the course to jobs in hospitals and, in some cases, accelerate the completion of undergraduate courses with the objective of increasing the active workforce. Some recent international publications claim that nursing and medical students and interns feel caught between the gratifying possibilities of contributing and learning from the pandemic and the concern of contracting the disease or contaminating their family members, or even causing damage to patients through malpractice. Such contradictory feelings cause moral distress in students ${ }^{34,35}$. Reflections on students' difficult decisions lead us to think about the possibility that they could contribute in other, safer ways by developing, for example, health promotion and education actions in communities or creating and disseminating educational materials on social media ${ }^{36}$.

Within the context of stimulating the development of research on COVID-19 and training postgraduate professionals in the areas of health, $\mathrm{CNPq}$ and CAPES (Brazilian agencies which promote and support research and postgraduate studies) announced, in recent months, public calls that aimed to contribute to the advancement of knowledge, training of human resources, generation of products, formulation, implementation and evaluation of public actions aimed at improving conditions to deal with the pandemic. The education system and support for scientific 
activities in general, however, are under constant threat, with budget cuts and lack of planning for the sector during and post-pandemic.

The lack of coordination by the authorities together with a succession of errors made by the federal government seems to be related to the multiplication of deaths caused by COVID-19 in the country, including deaths of health professionals. Coping with the pandemic in Brazil has required creativity and the ability to mobilize HCPs and health care institutions individually, far beyond the official directives and protocols, as a possibility to transform the work process of health professionals and encourage an interprofessional context. When examining recent legislation, it is evident that there is no leadership dedicated to formulating comprehensive policies and strategies that can deal with the fragmentation that prevails in all governmental bodies in the country. A committee to tackle the pandemic, interested in developing long-term strategic understanding, based on science, could increase cooperation and define the priorities of each region of the country. A coordinated approach to actions, involving all those dealing with the COVID-19 pandemic, is necessary to define priorities, especially in a scenario with challenges as complex and diverse as the Brazilian reality.

\section{Final considerations}

The absence of a federal policy coordinating actions aimed at the governance of the health workforce to face the pandemic in Brazil has been noted. The opposing position of Federal Councils of health professions to federal regulations corroborates this perception. This absence contributes decisively to the tragic epidemiological situation, both in terms of the general population and in terms of infection and mortality of HCP from COVID-19. The published regulations include isolated, superficial, repetitive and insufficient aspects as a set of measures to resize the workforce and enable it to properly manage the pandemic, as well as to protect it in terms of working conditions, physical and mental health, and labor rights by recognizing COVID-19 as an occupational disease.

These findings, added to the lack of transparency regarding the illness and death of health workers, reveal the immense carelessness in relation to professionals in the area and, consequently, the population itself. This neglect was evidenced by other recent actions of the federal government, widely disseminated by the media: the presidential veto of laws that provided compensation to disabled professionals after contracting SARS-CoV2 while working; vetoes on proposals that defined measures to combat the spread of the disease among indigenous, quilombola and traditional communities; vetoes of bills that required the use of masks in places such as churches, shops, schools and prisons. By July 2020 , when the country had already accounted for almost 100,000 deaths from COVID-19, the federal government had invested only $29 \%$ of the financial resources that had been earmarked to combat the pandemic, and the Ministry of Health remained without an appointed Minister. In this context, the initiatives of the states and municipalities, as well as those of the professional health councils end up assuming a leading role in dealing with some of the gaps left by the federal executive without, however, being able to replace it in the strategic management of COVID-19.

The conclusions of this research need to be considered in the context of the serious Brazilian political crisis, which further intensifies the health crisis triggered by the pandemic, and vice versa. After the official figure of more than 8 million contaminated and more than 200 thousand Brazilians killed by COVID-19, and the uncertainties regarding the vaccination plan, such conclusions reinforce a dramatic appeal for the immediate organization of a national response on a scale that the ongoing tragedy demands, in order to mitigate its irreversible consequences to Brazilian society and its health workers. This is a duty of the Brazilian State and a right of its citizens and workers. 


\section{Collaborators}

MF Vasquez performed the data collection, analysis and writing. SN Leite, M Finkler, JG Martini, M Verdi, I Heidemann and F Hellmann performed the study design, data analysis, writing and critical review of the manuscript.

\section{References}

1. Nagesh S, Chakraborty S. Saving the frontline health workforce amidst the COVID-19 crisis: Challenges and recommendations. J Glob Health 2020;10(1).

2. Litewka SG, Heitman E. Latin American healthcare systems in times of pandemic. Dev World Bioeth 2020; 20(2):69-73.

3. Fraher EP, Pittman P, Frogner B, Spetz J, Moore J, Beck AJ, Armstrong D, Buerhaus PI. Ensuring and sustaining a pandemic workforce. N Engl J Med. 2020; 382(23):2181-2183.

4. CDC. Characteristics of health care personnel with COVID-19 - United States, february 12-april 9, 2020. Morb Mortal Wkly Rep 2020; 69(15):477-481.

5. Black JRM, Bailey C, Przewrocka J, Dijkstra KK, Swanton C. COVID-19: the case for health-care worker screening to prevent hospital transmission. Lancet 2020; 395(10234):1418-1420.

6. Guan W, Ni Z, Hu Y, China Medical Treatment Expert Group for Covid-19. Clinical characteristics of coronavirus disease 2019 in China. N Engl J Me 2020; 382(18):1708-1720.

7. Nucléo de estudos da burocracia (NEB/FGV). A pandemia de COVID-19 e os profissionais de saúde Pública no Brasil [nota técnica] 2020. [acessado $2021 \mathrm{fev} 8$ ]. Disponível em: https://www.conass.org.br/pesquisa -impactos-do-coronavirus-nos-profissionais-de-saude/

8. Brasil. Conselho Federal de Enfermagem (COFEN). Profissionais infetados com COVID-19 informado pelo serviço de saúde. [acessado 2021 jan 13]. Disponível em: http://observatoriodaenfermagem.cofen.gov.br/

9. Heinzerling A, Struckey M, Sheuer T, Xu K, Perkins KM, Resseger H, Magill S, Verani JR, Jain S, Acosta M, Epson E. Transmission of COVID-19 to Health Care Personnel during exposures to a Hospitalized PatientSolano County, California, February, 2020. Morb Mortal Weekly Rep 2020; 69(15):472-476.

10. Tanne JH, Hayasaki E, Zastrow M, Pulla P, Smith P, Rada AG. COVID-19: how doctors and healthcare systems are tackling coronavirus worldwide. BMJ 2020; 368(m1090):1-5.

11. Dewey C, Hingle S, Goelz E, Linzer M. Supporting clinicians during the COVID-19 pandemic. Ann Intern Med 2020; 172(11):752-753.

12. Luo M, Guo L, Yu M, Jiang W, Wang H. The psychological and mental impact of coronavirus disease 2019 (COVID-19) on medical staff and general public - a systematic review and meta-analysis. Psychiatry Res 2020; 291(113190).

13. Lai J, Ma S, Wang Y, Cai Z, Hu J, Wei N, Wu J, Du H, Chen T, Li R, Tan H, Kand L, Yao L, Huand M, Wang H, Wang G, Liu Z, Hu S. Factors associated with mental health outcomes among health care workers exposed to coronavirus disease 2019. JAMA Netw Open 2020; 3(3):203976.

14. Ersoy A. The frontline of the COVID-19 pandemic: Healthcare workers. Turkish J Intern Med 2020; 2(2):31-32.

15. Johns S. COVID-19 in Brazil : Research reveals how epidemic spread around country. Imperial College London; 2020 Jul 20; [cited 2020 Aug 19]. Available from: https://bit.ly/31qPMzv 
16. Brasil. COVID-19. Painel coronavirus. SUS 2020 [acessado 2021 jan 10]. Disponível em: https://covid. saude.gov.br/

17. Lotta G, Wenham C, Nunes J, Pimenta DN. Community health workers reveal COVID-19 disaster in Brazil. Lancet 2020; 396(10248):365-366.

18. COVID-19 in Brazil: "So what?" [editorial] Lancet 2020; 395(10235):1461.

19. World Health Organization (WHO). The World Health Report 2006 - working together for health. Geneva: WHO; 2006. $237 \mathrm{p}$.

20. Brasil. Conselho Nacional de Secretários de Saúde (CONASS). [acessado 2020 abr 15]. Disponível em: https://www.conass.org.br/

21. Brasil. Presidência da Républica. Secretaria geral. Subchefia para assuntos jurídicos. Atualização diária dos atos normativos sobre a COVID-19 [acessado 2020 Abr 6]. Disponível em: http://www.planalto.gov.br/ CCIVIL_03/Portaria/quadro_portaria.htm

22. Brasil. Ministério da Saúde (MS). Secretaria Especial de Saúde Indigena. Boletin epidemiológico da SESAI. Brasília: MS; 2021 [acessado 2021 Jan 13]. Disponível em: https://saudeindigena.saude.gov.br/corona

23. Instituto Socioambiental (ISA). COVID-19 e os povos indígenas. Plataforma de monitoramento da situação indígena na pandemia do novo coronavírus (COVID-19) no Brasil. São Paulo: ISA; 2020 [acessado 2021 jan 13]. Disponível em: https://covid19.socioambiental.org/

24. World Health Organization (WHO). Working for Health and Growth: Investing in the Health Workforce. Report of the High-Level Commission on Health Employment and Economic Growth. Geneva: WHO; 2016.

25. Pacheco Santos LM, Millett C, Rasella D, Hone T. The end of Brazil's More Doctors programme? BMJ 2018; 363:12-13

26. Fiho JMJ, Assunção AÁ, Algranti E, Garcia EG, Saito CA, Maeno M. A saúde do trabalhador e o enfrentamento da COVID-19. Rev Bras Saude Ocup 2020; 45(e14):10-12.

27. Griffin MF. An invited commentary: international surgical guidance for COVID-19: validation using an international Delphi process. Int J Surg 2020; 80:4142.

28. Amnesty International. Exposed, Silenced, Attacked: Failures to Protect Health and Essential Workers during the COVID-19 Pandemic. London: Amnesty International; 2020.

29. Oliveira AEF, Ferreira EB, Souza RR, Castro Junior EF, Moura MFL. Educação a distância e formação continuada: em busca de progressos para a saúde. Rev Bras Educ Med 2013; 37(4):578-583. [acessado $2021 \mathrm{fev}$ 10]. Disponível em: http://www.scielo.br/pdf/rbem/ v37n4/a14v37n4.pdf
30. Brasil. Associação Brasileira de Enfermagem (ABEn). Nota da ABEn Nacional em relação à ação estratégica "O Brasil conta comigo." Brasília: ABEn: 2020 [Acessado 2020 jul 5]. Disponível em: https://bit.ly/3aZqdJd

31. Brasil. Conselho Federal de Enfermagem (Cofen). Cofen se manifesta sobre Portaria $n^{\circ} 356$ do MEC [nota oficial]; Brasília: Cofen; 2020. [acessado 2020 jul 14]. Disponível em: http://www.cofen.gov.br/cofense-manifesta-sobre-a-portaria-356-do-mec_78941. html

32. Miller DG, Pierson L, Doernberg S. The role of medical students during the COVID-19 pandemic. Ann Intern Med 2020; 173(2):145-146.

33. Choi B, Jegatheeswaran L, Minocha A, Alhilani M, Nakhoul M, Mutengesa E. The impact of the COVID-19 pandemic on final year medical students in the United Kingdom: a national survey. BMC Med Educ 2020; 20(1):206.

34. Swift A, Banks L, Baleswaran A, Cooke N, Little C, McGrath L, Meechan-Rogers R, Neve A, Rees H, Tomlinson A, Williams G. COVID-19 and student nurses: A view from England. J Clin Nurs 2020; 29(1718):3111-3114.

35. Gallagher T, Schleyer A. "We Signed Up for This!"Student and trainee responses to the COVID-19 pandemic. N Engl J Med 2020; 96(1):1-2.

36. Rose S. Medical student education in the time of COVID-19. JAMA Netw Open 2020; 323(2131-2132).

37. Kripka R, Scheller M, Bonotto DDL. La investigación documental sobre la investigación cualitativa: conceptos y caracterización. Rev Invest UNAD 2015; 14(2): 55-73.

Article submitted 18/09/2020

Approved 01/02/2021

Final version submitted 03/02/2021

Chiefs Editors: Romeu Gomes, Antônio Augusto Moura da Silva 